\title{
Targeted delivery of tissue plasminogen activator by binding to silica-coated magnetic nanoparticle
}

\author{
This article was published in the following Dove Press journal: \\ International Journal of Nanomedicine \\ 26 September 2012 \\ Number of times this article has been viewed
}

\author{
Jyh-Ping Chen' \\ Pei-Ching Yang' \\ Yunn-Hwa $\mathrm{Ma}^{2}$ \\ Su-Ju Tu ${ }^{3}$ \\ Yu-Jen Lu ${ }^{1,4}$ \\ 'Department of Chemical and \\ Materials Engineering, ${ }^{2}$ Department \\ of Physiology and Pharmacology, \\ ${ }^{3}$ Department of Medical Imaging and \\ Radiological Sciences, Chang Gung \\ University, Kwei-San, Taoyuan, Taiwan, \\ Republic of China; ${ }^{4}$ Department of \\ Neurosurgery, Chang Gung Memorial \\ Hospital, Kwei-San, Taoyuan, Taiwan, \\ Republic of China
}

Background and methods: Silica-coated magnetic nanoparticle $\left(\mathrm{SiO}_{2}-\mathrm{MNP}\right)$ prepared by the sol-gel method was studied as a nanocarrier for targeted delivery of tissue plasminogen activator (tPA). The nanocarrier consists of a superparamagnetic iron oxide core and an $\mathrm{SiO}_{2}$ shell and is characterized by transmission electron microscopy, Fourier transform infrared spectroscopy, $\mathrm{X}$-ray diffraction, superconducting quantum interference device, and thermogravimetric analysis. An amine-terminated surface silanizing agent (3-aminopropyltrimethoxysilane) was used to functionalize the $\mathrm{SiO}_{2}$ surface, which provides abundant $-\mathrm{NH}_{2}$ functional groups for conjugating with tPA.

Results: The optimum drug loading is reached when $0.5 \mathrm{mg} / \mathrm{mL}$ tPA is conjugated with $5 \mathrm{mg}$ $\mathrm{SiO}_{2}-\mathrm{MNP}$ where $94 \%$ tPA is attached to the carrier with $86 \%$ retention of amidolytic activity and full retention of fibrinolytic activity. In vitro biocompatibility determined by lactate dehydrogenase release and cell proliferation indicated that $\mathrm{SiO}_{2}-\mathrm{MNP}$ does not elicit cytotoxicity. Hematological analysis of blood samples withdrawn from mice after venous administration indicates that tPA-conjugated $\mathrm{SiO}_{2}-\mathrm{MNP}\left(\mathrm{SiO}_{2}\right.$-MNP-tPA) did not alter blood component concentrations. After conjugating to $\mathrm{SiO}_{2}-\mathrm{MNP}$, tPA showed enhanced storage stability in buffer and operation stability in whole blood up to 9.5 and 2.8-fold, respectively. Effective thrombolysis with $\mathrm{SiO}_{2}$-MNP-tPA under magnetic guidance is demonstrated in an ex vivo thrombolysis model where $34 \%$ and $40 \%$ reductions in blood clot lysis time were observed compared with runs without magnetic targeting and with free tPA, respectively, using the same drug dosage. Enhanced penetration of $\mathrm{SiO}_{2}$-MNP-tPA into blood clots under magnetic guidance was confirmed from microcomputed tomography analysis.

Conclusion: Biocompatible $\mathrm{SiO}_{2}-\mathrm{MNP}$ developed in this study will be useful as a magnetic targeting drug carrier to improve clinical thrombolytic therapy.

Keywords: magnetic nanoparticles, drug delivery, thrombolysis, tissue plasminogen activator, silica

\section{Introduction}

Superparamagnetic iron oxide $\left(\mathrm{Fe}_{3} \mathrm{O}_{4}\right)$ is a promising candidate for biomedical applications because of its strong magnetic properties and biocompatibility, as well as its unique multifunctional properties. ${ }^{1,2}$ Magnetic nanoparticle (MNP) based on $\mathrm{Fe}_{3} \mathrm{O}_{4}$ can be applied in drug delivery, bioseparation, biosensing, contrast agents for magnetic resonance imaging (MRI), and for magnetically induced cancer hyperthermia. ${ }^{3-7}$ As a drug carrier, MNP is usually composed of a superparamagnetic $\mathrm{Fe}_{3} \mathrm{O}_{4}$ core and a polymer coating layer, which provides functional groups facilitating drug binding, inhibiting aggregation, and increasing colloidal stability. ${ }^{8-10}$ Other than polymer coating, silica has been known to be one of the most ideal coating layers for $\mathrm{Fe}_{3} \mathrm{O}_{4}$-MNP
Department of Chemical and Materials Engineering, Chang Gung University, Kwei-San, Taoyuan 333, Taiwan,

Republic of China

Tel +88632118800

Fax +88632118668

Email jpchen@mail.cgu.edu.tw 
due to its reliable chemical stability, biocompatibility, and reactivity with various coupling agents, making them suitable for conjugation with drugs for in vivo applications. ${ }^{11}$ In addition, amorphous silica particles have surface hydroxyl groups that render them intrinsically hydrophilic, which should decrease oxide particle clearance by the reticuloendothelial system, and thus increase their circulation time in the blood. ${ }^{12}$ When used as the coating material, silica is not subject to microbial attack and neither swells nor changes porosity in response to environmental $\mathrm{pH}$ values. ${ }^{13}$ There are few reports using silica-coated magnetic nanoparticle $\left(\mathrm{SiO}_{2}-\mathrm{MNP}\right)$ in targeted drug-delivery systems. ${ }^{14-16}$ Typically, there are two kinds of methods by which to prepare $\mathrm{SiO}_{2}-\mathrm{MNP}$. The first method is based on the microemulsion system, in which the $\mathrm{Fe}_{3} \mathrm{O}_{4}-\mathrm{MNP}$ is restricted in the water droplets dispersed in a continuous organic phase and $\mathrm{SiO}_{2}-\mathrm{MNP}$ is formed by hydrolysis and condensation of tetraethoxysilane (TEOS), which diffuses from the surrounding organic phase into the water droplet. ${ }^{17,18}$ The microemulsion method will allow better control to achieve the composite particles with tunable size and shell thickness. However, it is hard to produce magnetic composite particles with submicron size with this method. ${ }^{19}$ The second method is based on the Stöber process, in which silica is formed by the hydrolysis and condensation of TEOS in an ethanol-ammonia mixture. ${ }^{20,21}$ The Stöber process is the prevailing choice for coating $\mathrm{Fe}_{3} \mathrm{O}_{4}$-MNP with silica, and has been proved to be an easy and efficient way to acquire silica-coated magnetic spheres. ${ }^{19}$

Myocardial infarction and venous thromboembolism are the major causes of cardiovascular mortality, which results in over 1 million deaths each year in the US. ${ }^{22,23}$ Thrombosis, beginning with endothelial injury followed by platelet activation, is responsible for most of the pathophysiology of these diseases. Thrombolytic drug therapy can reduce mortality, and this therapeutic approach has been widely used in thrombosis treatment. ${ }^{24}$ Although a number of thrombolytic drugs are currently available, tissue plasminogen activator (tPA) is currently the only US Food and Drug Administration-approved therapy for lysis of fibrin clot in treating ischemic stroke. ${ }^{25} \mathrm{tPA}$ is a serine protease that converts the zymogen plasminogen to plasmin, which then initiates the process of lysis of the fibrin clot (fibrinolysis). ${ }^{26}$ As tPA has a very short life in plasma (half-life $\approx 5$ minutes), ${ }^{27}$ it needs to be administered at a high dose for a prolonged period of time in order to maintain an effective drug level during thrombolytic drug therapy, which leads to degradation of clotting factors and hemorrhage. ${ }^{28}$ It will therefore be highly desirable to deliver tPA under guidance for targeted thrombolysis, which will allow tPA to be localized to the target site and reduce its hemorrhagic side effects. ${ }^{29-31}$ Target delivery of tPA using MNP as a drug carrier could meet this need by retaining the drug under magnetic guidance. ${ }^{32}$ Thus, delivery of tPA by binding the thrombolytic drug to $\mathrm{SiO}_{2}$-MNP will ensure that the drug is delivered under magnetic guidance and retained in a local area in circulation, which is potentially useful for targeting fibrin clot in vivo.

In this study, we examine the preparation of $\mathrm{SiO}_{2}-\mathrm{MNP}$ by the sol-gel method and the feasibility to use it as a magnetic nanocarrier for delivery of $\mathrm{tPA}$. $\mathrm{SiO}_{2}-\mathrm{MNP}$ consisting of a superparamagnetic core and an $\mathrm{SiO}_{2}$ shell was synthesized and characterized. An amine-terminated surface silanizing agent (3-aminopropyltrimethoxysilane) was used to functionalize the $\mathrm{SiO}_{2}$ surface, which provides abundant $-\mathrm{NH}_{2}$ functional groups for conjugating with tPA. After covalent binding to $\mathrm{SiO}_{2}-\mathrm{MNP}$, tPA showed high activity retention and enhanced storage and operation stability. Effective thrombolysis with $\mathrm{SiO}_{2}$-MNP-tPA under magnetic guidance substantially reduced blood clot lysis time compared with runs without magnetic targeting and with free tPA using the same drug dosage. The results demonstrate that $\mathrm{SiO}_{2}-\mathrm{MNP}$ is a useful magnetic targeting drug carrier for tPA delivery, and $\mathrm{SiO}_{2}-\mathrm{MNP}$-tPA may provide a new form of thrombolytic drug that is potentially useful for treatment of thrombus.

\section{Materials and methods Materials}

The raw Fe(II) chloride tetrahydate (99\%) and $\mathrm{Fe}(\mathrm{III})$ chloride hexahydrate $(97 \%)$ were purchased from Acros (Geel, Belgium). tPA (Actilyse ${ }^{\circledR}$ ) was obtained from Boehringer Ingelheim (Mannheim, Germany). TEOS was obtained from Fluka (Buchs, Germany). The crosslinking agent glutaraldehyde (GA) was obtained from Merck \& Co (Whitehouse Station, NJ). 3-aminopropyltriethoxysilane (APTES), o-phthaldialdehyde, thrombin, fibrinogen, and 3-(4,5-dimethylthiazol-2-yl)-2,5-diphenyl-tetrazolium bromide (MTT) were obtained from Sigma-Aldrich (St Louis, $\mathrm{MO}$ ). The chromogenic substrate H-D-Isoleucyl-L-prolylL-arginine-p-nitroaniline (S-2288) was obtained from Chromogenix (Milano, Italy). All the chemicals were of reagent grade and used without further purification.

\section{Synthesis of $\mathrm{Fe}_{3} \mathrm{O}_{4}$ magnetic nanoparticles and silica-coated magnetic nanoparticles}

$\mathrm{Fe}_{3} \mathrm{O}_{4}$-MNP was obtained by reacting $0.22 \mathrm{M} \mathrm{FeCl}_{3} \cdot 6 \mathrm{H}_{2} \mathrm{O}$ and $0.11 \mathrm{M}$ of $\mathrm{FeCl}_{2} \cdot 4 \mathrm{H}_{2} \mathrm{O}\left(\mathrm{Fe}^{+3}: \mathrm{Fe}^{+2}=2: 1\right)$ in distilled deionized (DDI) water at $60^{\circ} \mathrm{C}$ under nitrogen atmosphere for 1 hour. Four milliliters of $25 \% \mathrm{NH}_{4} \mathrm{OH}$ was added to the 
solution, after which the color of the mixture turned from yellow to black immediately, and the solution was stirred at $400 \mathrm{rpm}$ for another 20 minutes. The synthesized $\mathrm{Fe}_{3} \mathrm{O}_{4}-$ MNP was washed three times with DDI and separated by magnetic decantation, dialyzed $(\mathrm{MWCO}=3500)$ for 7 days against DDI water with daily water change, and stored at $4^{\circ} \mathrm{C}$. $\mathrm{SiO}_{2}-\mathrm{MNP}$ was prepared by mixing $50 \mathrm{~mL}$ ethanol, $1 \mathrm{~mL}$ DDI water, and $1.5 \mathrm{~mL}$ TEOS in a $250 \mathrm{~mL}$ four-neck flask in a $40^{\circ} \mathrm{C}$ water bath under mechanical stirring for 20 minutes at $1500 \mathrm{rpm}$. Two milliliters of $25 \% \mathrm{NH}_{4} \mathrm{OH}$ was added to the solution under stirring and reacted for $20 \mathrm{~min}$ utes, followed by adding $60 \mathrm{~mL} \mathrm{Fe}_{3} \mathrm{O}_{4}$-MNP $(0.18 \mathrm{mg} / \mathrm{mL})$ under stirring for another 6 hours. $\mathrm{SiO}_{2}$-MNP was isolated with a magnet to eliminate the homogeneous silica nucleus and dried at $90^{\circ} \mathrm{C}$ under vacuum after being washed three times with ethanol.

Amine-derived $\mathrm{SiO}_{2}$-MNP was prepared by modifying $\mathrm{SiO}_{2}$-MNP with APTES to introduce surface amine groups (Figure 1, step 1). Fifteen milligrams of $\mathrm{SiO}_{2}-\mathrm{MNP}$ was treated in $4 \mathrm{~mL}$ ethanol $/ 1 \mathrm{~mL}$ DDI water for 30 minutes with an ultrasonic processor (Misonix Sonicator 4000; Qsonica, LLC, Newtown, CT) at $600 \mathrm{~W}$, and $0.25 \mathrm{~mL}$ APTES and $0.25 \mathrm{~mL}$ dimethylformamide was added. The solution was shaken at $200 \mathrm{rpm}$ in an incubator for 2 hours, and $\mathrm{SiO}_{2}-\mathrm{MNP}$ was isolated with a magnet after washing with phosphate-buffered saline (PBS) three times and stored in PBS at $1 \mathrm{mg} / \mathrm{mL}$.

\section{Characterization of magnetic nanoparticles}

The particle size and morphology of MNP were examined by transmission electron microscopy (TEM) (JEM-2000 EX II; JEOL, Tokyo, Japan). An aqueous dispersion of the particles was drop-cast on to a carbon-coated copper grid, and the grid was air-dried at room temperature before loading into the microscope. Alternatively, the sample was stained with $2 \%$ phosphotungstic acid (PTA) aqueous solution for 3 minutes before analysis.

To investigate the crystal structure of the NP, wideangle X-ray diffraction (XRD) spectra were registered
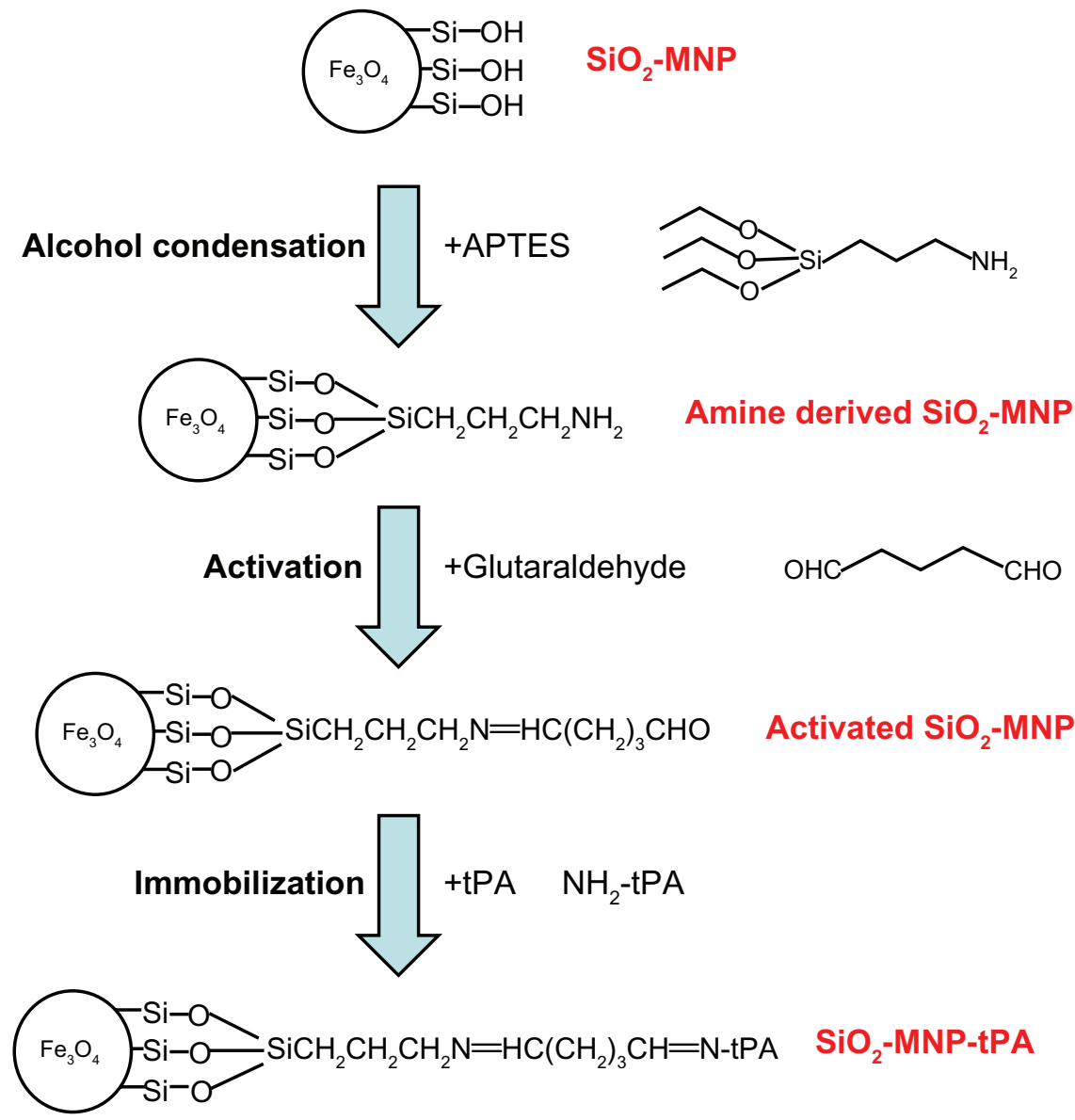

Figure I A schematic diagram showing the surface modification of silica-coated magnetic nanoparticle ( $\mathrm{SiO}_{2}$-MNP) with 3-aminopropyltriethoxysilane (APTES) (step I), activation with glutaraldehyde (step 2), and immobilization of tissue plasminogen activator (tPA) (step 3). 
with a Siemens D5005 diffractometer (Siemens AG, Erlangen, Germany) composed of a $\mathrm{CuK}_{\alpha}$ source, a quartz monochrometer, and a geniometric plate at a scanning speed of $2^{\circ} \mathrm{min}^{-1}$ from $15^{\circ}$ to $70^{\circ}$. The zeta potential and the particle size distributions were determined using laser dynamic light scattering with Malvern Zetasizer ZA 90 (Malvern Instruments, Malvern, UK) in water at $25^{\circ} \mathrm{C}$. The magnetization of the NP was measured by a superconducting quantum interference device (SQUID) magnetometer (MPMS XL-7; Quantum Design, San Diego, CA) at $25^{\circ} \mathrm{C}$ and $\pm 10,000 \mathrm{G}$ applied magnetic field. For Fourier transform infrared spectroscopy (FTIR) measurement using a Horiba FT-730 spectrometer, the samples were blended with $\mathrm{KBr}$ and then compressed to form a pellet. The transmission spectra were obtained from 450 to $4000 \mathrm{~cm}^{-1}$ with a resolution of $4 \mathrm{~cm}^{-1}$. Concentrations of amino groups on the surface of $\mathrm{SiO}_{2}-\mathrm{MNP}$ were determined by the o-phthaldialdehyde method, which is based on the reaction of primary amines with an excess of o-phthaldialdehyde and $\beta$-mercaptoethanol and subsequent quantitative determination of unreacted o-phthaldialdehyde by reaction with glycine. ${ }^{33}$ The iron contents of $\mathrm{SiO}_{2}-\mathrm{MNP}$ were analyzed by inductively coupled plasma optical emission spectroscopy (Optima 2100 DV; PerkinElmer, Waltham, MA). Thermogravimetric analysis (TGA) was conducted with TGA 2050 from TA instruments (New Castle, DE).

For in vitro biocompatibility test, the cytotoxic effect of $\mathrm{SiO}_{2}-\mathrm{MNP}$ was tested on a mouse embryonic fibroblast cell line (3T3). 3T3 cells were cultured using 24-well culture plates $\left(1.0 \times 10^{4}\right.$ cells/well $)$ in Dulbecco's modified Eagle's medium (DMEM) supplemented with 10\% fetal bovine serum and incubated at $37^{\circ} \mathrm{C}$ in a $5 \% \mathrm{CO}_{2}$ atmosphere. After 24 hours of culture, the medium in the wells was replaced with fresh medium containing $\mathrm{SiO}_{2}-\mathrm{MNP}$ at a concentration ranging from $10^{-4}$ to $10^{6} \mathrm{ng} / \mathrm{mL}$ and cultured for another 3 days before measuring mitochondria activity by MTT assays. Forty microliters of MTT solution $(5 \mathrm{mg} / \mathrm{mL}$ in $0.1 \mathrm{M}$ phosphate buffer, pH 7.4) and $200 \mu \mathrm{L}$ PBS were added to each well. After 3 hours' incubation at $37^{\circ} \mathrm{C}$ in $5 \% \mathrm{CO}_{2}$, the medium was removed and the formazan crystals were dissolved in $1 \mathrm{~mL}$ of dimethylsulfoxide. The solution was mixed vigorously to dissolve the crystal product. The optical density (OD) of solution in each well was recorded on a microplate reader (BioTek Synergy HT; BioTek, Winooski, VT) at $570 \mathrm{~nm}\left(\mathrm{OD}_{570}\right)$. For detection of cell damage caused by $\mathrm{SiO}_{2}-\mathrm{MNP}$, the same procedure was followed, except $50 \mu \mathrm{L}$ of medium was removed 1 day after adding $\mathrm{SiO}_{2}-\mathrm{MNP}$ to measure the lactate dehydrogenase (LDH) concentration secreted by cells with a commercial LDH assay kit from Promega (Madison, WI) using a microplate reader at $490 \mathrm{~nm}\left(\mathrm{OD}_{490}\right) .3 \mathrm{~T} 3$ cells without contacting $\mathrm{SiO}_{2}$-MNP were used as the control.

MRI was carried out in C57BL/6 mice to show that asprepared NP could be used as an imaging agent and visualized in MRI. The experiments were improved by the Institutional Animal Care and Use Committee of Chang Gung Memorial Hospital (Kwei-San, Taoyuan, Taiwan) and adhered to the experimental care guidelines. Animals were assessed by MRI 120 minutes after tail vein injection of $0.1 \mathrm{~mL}$ of PBS (control) or $0.1 \mathrm{~mL}$ of $10 \mathrm{mg} / \mathrm{mL} \mathrm{SiO}_{2}$-MNP in PBS. All MR images were acquired on a 3-T scanner (MAGNETOM Trio, A Tim System; Siemens Healthcare, Erlangen, Germany) using the standard wrist coil with an inner diameter of $13 \mathrm{~cm}$. The animals were anesthetized with $2 \%$ isoflurane throughout the MRI process, placed in an acrylic holder, and positioned at the center of the magnet.

\section{Immobilization and activity assays of tissue plasminogen activator}

tPA was immobilized using GA as a crosslinking agent to promote the formation of imide bonds between the aldehyde groups of GA and amino groups of $\mathrm{SiO}_{2}-\mathrm{MNP}$ or tPA. Five milligrams of $\mathrm{SiO}_{2}-\mathrm{MNP}$ suspension was mixed with $0.1 \mathrm{~mL}$ of $0.5 \%$ GA for 30 minutes in $0.5 \mathrm{~mL}$ PBS ( $\mathrm{pH} 7.4$ ) with shaking $(200 \mathrm{rpm})$ at $30^{\circ} \mathrm{C}$, followed by washing twice with $1 \mathrm{~mL}$ PBS ( $\mathrm{pH} 7.4$ ) to prepare activated $\mathrm{SiO}_{2}-\mathrm{MNP}$ (Figure 1, step 2). Two hundred and fifty microliters of activated $\mathrm{SiO}_{2}$-MNP $(20 \mathrm{mg} / \mathrm{mL})$ was then mixed with $0.25 \mathrm{~mL}$ of tPA solution for 12 hours at $4^{\circ} \mathrm{C}$ using a rotator at $6 \mathrm{rpm}$ to obtain $\mathrm{SiO}_{2}$-MNP-tPA (Figure 1, step 3). Immobilized tPA could be obtained after magnetic separation from the solution and washing with PBS. The amount of tPA immobilized to $\mathrm{SiO}_{2}-\mathrm{MNP}$ was determined by measuring unbound tPA protein concentrations in the supernatant and the washing solution by a colorimetric method at $595 \mathrm{~nm}$ with the Protein Assay Kit from Bio-Rad (Hercules, CA). Protein loading efficiency was defined as the percentage of tPA protein bound to $\mathrm{SiO}_{2}-\mathrm{MNP}$ in comparison with that added initially during the immobilization step.

Amidolytic activity of tPA was measured spectrophotometrically using the protease substrate S-2288, a specific chromogenic substrate for tPA, according to the manufacturer's instruction. Activity retention after immobilization was defined as the percentage of specific activity (U/mg) of immobilized tPA compared with that of free tPA, which is $2.43 \mathrm{U} / \mathrm{mg}$. Fibrinolytic activity of tPA was determined from fibrin clot lysis assay using fibrin-containing agarose plates. $^{34}$ The plates were prepared by mixing $10 \mathrm{~mL}$ low 
melting temperature agarose solution ( $5 \%$ ) containing $2.5 \mathrm{U}$ thrombin with $5.0 \mathrm{~mL}$ fibrinogen solution $(5 \mathrm{mg} / \mathrm{mL})$ at $50^{\circ} \mathrm{C}$. The reaction mixture was poured into a $9 \mathrm{~cm}$ culture dish and cooled at $4^{\circ} \mathrm{C}$ for 30 minutes until the fibrin clot became visible. To perform the assays, $0.1 \mathrm{~mL}$ solution ( $\mathrm{tPA}$ or $\mathrm{SiO}_{2}$ MNP-tPA) was added into the round sample wells (3 mm diameter) made on the solid fibrin-agarose gel and incubated at $37^{\circ} \mathrm{C}$ for 1 hour. The degree of fibrin lysis was quantified by comparing the size of the fibrinolysis zone around sample wells containing equivalent tPA concentrations. A linear calibration curve could be established for the diameter of fibrin lysis zone versus tPA concentration from 0 to $2 \mathrm{mg} / \mathrm{mL}$.

\section{Storage stability, operation stability, and blood compatibility of $\mathrm{SiO}_{2}-$ MNP-tPA} Storage stability of free and immobilized tPA was determined from the residual activity of tPA after storage in PBS at $4^{\circ} \mathrm{C}$. Ten milliliters of PBS containing free tPA $(1 \mathrm{mg} / \mathrm{mL}$ tPA $)$ or $10 \mathrm{mg} / \mathrm{mL} \mathrm{SiO}_{2}$-MNP-tPA solution (equivalent to $1 \mathrm{mg} / \mathrm{mL}$ tPA) was incubated under static condition. Samples $(0.1 \mathrm{~mL})$ were withdrawn at times and assayed for residual amidolytic activity. Relative activity was determined by normalizing the residual activity measured for each sample at different times with its initial amidolytic activity.

Operation stability was determined by preparing $10 \mathrm{~mL}$ whole blood containing free tPA ( $2 \mathrm{mg} / \mathrm{mL}$ tPA $)$ or $20 \mathrm{mg} / \mathrm{mL}$ $\mathrm{SiO}_{2}$-MNP-tPA (equivalent $2 \mathrm{mg} / \mathrm{mL}$ tPA) and incubated at $37^{\circ} \mathrm{C}$ under static condition. Samples $(0.3 \mathrm{~mL})$ were withdrawn at 5, 10, 30, and 45 minutes and assayed for residual fibrinolytic activity by comparing the diameter of the fibrinolysis zone around sample wells.

For blood compatibility, hematological measurements were carried out in C57BL/6 mice. The experiments were approved by the Institutional Animal Care and Use Committee of Chang Gung University and adhered to the experimental care guidelines. One milliliter of blood samples was collected via the tail vein 120 minutes after venous administration of $0.1 \mathrm{~mL}$ PBS (control), tPA in PBS (1 mg/mL), $10 \mathrm{mg} / \mathrm{mL} \mathrm{SiO}_{2}-\mathrm{MNP}$ in PBS, or $10 \mathrm{mg} / \mathrm{mL} \mathrm{SiO}_{2}$-MNP-tPA in PBS (equivalent to $1 \mathrm{mg} / \mathrm{mL}$ tPA). Concentrations of red blood cells (RBCs), white blood cells (WBCs), platelets, hemoglobin, and hematocrit were determined by an automated hematology system (Sysmex XE-5000; Sysmex Co, Kobe, Japan).

\section{Blood clot lysis and micro-CT analysis}

Blood clot lysis induced by free tPA or $\mathrm{SiO}_{2}-\mathrm{MNP}$-tPA was determined by an ex vivo thrombolysis model driven by a constant pressure gradient at $37^{\circ} \mathrm{C}$ (Figure 2), which is similar to the condition that maintains blood circulation in vivo. ${ }^{35}$ A $0.02 \times 0.2 \times 30 \mathrm{~mm}$ collagen-coated glass capillary tube (Vitrotube; Vitrocom, Mountain Lakes, NJ) was vertically mounted below a reservoir (ID $=0.75 \mathrm{~cm}$ ) and immersed in a PBS bath. Whole blood samples $(0.5 \mathrm{~mL})$ were mixed with $0.1 \mathrm{~mL}$ of $0.9 \% \mathrm{NaCl}$ and $0.15 \% \mathrm{CaCl}_{2}$ solution containing $50 \mathrm{U}$ thrombin to produce a $0.8 \mathrm{~cm}$ height blood clot at the bottom of the reservoir. A solution of $0.2 \mathrm{mg} / \mathrm{mL} \mathrm{tPA}$, $2 \mathrm{mg} / \mathrm{mL} \mathrm{SiO}_{2}-\mathrm{MNP}$, or $2 \mathrm{mg} / \mathrm{mL} \mathrm{SiO}_{2}$-MNP-tPA (equivalent to $0.2 \mathrm{mg} \mathrm{tPA} / \mathrm{mL}$ ) was prepared in whole blood and introduced above the blood clot in the reservoir to a height of $0.2 \mathrm{~cm}$. For magnetic targeting, a magnet $(6000 \mathrm{G})$ was placed next to the bottom of the reservoir and rotated at $6 \mathrm{rpm}$ to introduce a magnetic guidance force down the blood clot at intervals. Blood generated from the clot was allowed to drain from the reservoir, through the capillary, into the PBS bath. Time to blood flow was recorded as the time when blood first exited from the capillary into the PBS bath.

Micro-CT studies were carried out to delineate the penetration depth of $\mathrm{SiO}_{2}$-MNP-tPA into the blood clots in a static lysis model and to demonstrate the dissemination of MNP within the clot matrix. Six hundred microliters of whole blood and $0.1 \mathrm{~mL}$ thrombin solution $(10 \mathrm{U} / \mathrm{mL})$ was mixed in a $2 \mathrm{~mL}$ plastic tube $(3 \mathrm{~cm}$ height $\times 1 \mathrm{~cm}$ diameter and sealed with $1 \mathrm{~cm}$ height polydimethylsiloxane silicone elastomer at the bottom) to form a blood clot. The individual blood clot was placed at the bottom of the tube, which allowed the clot to occupy the complete inner tube circumference, restricting the various treatments to remain in contact only with the clot surface. Two hundred microliters of $\mathrm{SiO}_{2}-\mathrm{MNP}$ or $\mathrm{SiO}_{2}$-MNP-tPA $(10 \mathrm{mg} / \mathrm{mL})$ in PBS was placed on top of the blood clot. A $6000 \mathrm{G}$ magnet $(1 \times 1 \times 8 \mathrm{~cm})$ was placed at the tube bottom for magnetic targeting when needed.

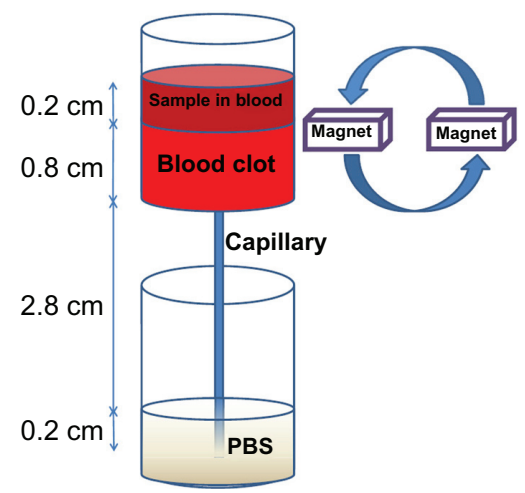

Figure 2 An ex vivo thrombolysis model for determining the thrombolysis efficacy of tissue plasminogen activator.

Abbreviation: PBS, phosphate-buffered saline. 
After 8 hours, the tube was incubated at $80^{\circ} \mathrm{C}$ to inactivate tPA and fix the NP, and the tube was subject to micro-CT imaging. A micro-CT scanner system (SkyScan 1076; SkyScan, Kontich, Belgium) was used in the imaging experiments. In micro-CT images, each pixel is associated with a linear attenuation coefficient that is a quantity to characterize the strength for a photon to pass through a material. For iron-based MNP, the physics of photoelectric effect is enhanced to generate contrast between NP and soft tissues. In this study, imaging energy of $50 \mathrm{keV}$, projection number of 720, a metal filter of aluminum with $0.5 \mathrm{~mm}$ thickness, spatial resolution of $8.9 \mu \mathrm{m}$, and reconstruction algorithm of filtered backprojection were used.

\section{Statistical analysis}

Values are expressed as mean \pm standard error and examined by one-way analysis of variance and Tukey's HSD test. Statistical significance was declared at $P<0.05$.

\section{Results and discussion Preparation and properties of silica-coated magnetic nanoparticles}

The chemical coprecipitation of ferrous and ferric cations in an alkaline solution is a classical method widely used for the preparation of $\mathrm{Fe}_{3} \mathrm{O}_{4}$-MNP. For further coating with silica using the Stöber method, ${ }^{36}$ due to the strong dipole-dipole interactions among the $\mathrm{Fe}_{3} \mathrm{O}_{4}$-MNP and increased ionic strength during the hydrolysis of TEOS, a first silica layer deposited on the $\mathrm{Fe}_{3} \mathrm{O}_{4}$-MNP surface is usually necessary to improve the dispersibility of the MNP before carrying out the silica coating by hydrolysis and condensation of TEOS. ${ }^{37} \mathrm{SiO}_{2}-\mathrm{MNP}$ was prepared in this study by direct introduction of $\mathrm{Fe}_{3} \mathrm{O}_{4}$-MNP into the Stöber process upon formation of the primary silica particles. When the $\mathrm{Fe}_{3} \mathrm{O}_{4}-\mathrm{MNP}$ was added into the reaction mixture at the appropriate time, the primary particles can quickly aggregate with the $\mathrm{Fe}_{3} \mathrm{O}_{4}$-MNP, thus suppressing the dipole-dipole interactions among the NP effectively and allowing the synthesis of composite $\mathrm{SiO}_{2}-\mathrm{MNP}$ with defined structure by further deposition of a silica layer. The prepared $\mathrm{SiO}_{2}-\mathrm{MNP}$ possesses excellent colloidal stability in solution and withstands repeated centrifugation/redispersion cycles without aggregation, which is the characteristic required for a magnetic nanosized carrier for tPA to effectively interact with fibrin clots.

Figure $3 \mathrm{~A}$ and $\mathrm{B}$ illustrates the TEM micrographs of the prepared $\mathrm{SiO}_{2}-\mathrm{MNP}$, which show uniform spherical particle morphology with $\sim 100 \mathrm{~nm}$ diameter. The NP has a core shell structure with a core electronic dense part (magnetite) surrounded by a silica shell of $10 \mathrm{~nm}$ thickness. Selected area electron diffraction pattern exhibits spots and rings of wellcrystallized magnetite $\mathrm{NPs}$ within $\mathrm{SiO}_{2}-\mathrm{MNP}$, indicating successful coating of $\mathrm{Fe}_{3} \mathrm{O}_{4}-\mathrm{MNP}$ surface with silica (Figure 3B, insert). The TEM micrograph of $\mathrm{SiO}_{2}-\mathrm{MNP}$ after conjugating tPA is shown in Figure 3C after PTA staining. Dynamic light scattering measurements show the hydrodynamic diameters of the $\mathrm{SiO}_{2}$-MNP to be about $200.5 \pm 3.1 \mathrm{~nm}$ with a rather monodisperse particle size distribution (polydispersive index $=0.138$ ). $\mathrm{Fe}_{3} \mathrm{O}_{4}$ content as determined by inductively coupled plasma is $57.1 \mathrm{wt} \% \mathrm{Fe}_{3} \mathrm{O}_{4}$ in $\mathrm{SiO}_{2}$-MNP. Electrophoretic mobility measurements give a highly negative zeta potential after silica coating where the zeta potentials changed from $18.8 \pm 0.9 \mathrm{mV}$ for $\mathrm{Fe}_{3} \mathrm{O}_{4}-\mathrm{MNP}$ to $-27.0 \pm 0.4 \mathrm{mV}$ for $\mathrm{SiO}_{2}-\mathrm{MNP}$ due to the presence of the negatively charged surface silanol group. After modifying $\mathrm{SiO}_{2}-\mathrm{MNP}$ surface with 3-aminopropyltriethoxysilane, the zeta potential of aminederived $\mathrm{SiO}_{2}-\mathrm{MNP}$ changes again to $33.2 \pm 1.8 \mathrm{mV}$ with the introduction of abundant positively charged amine groups on the surface. The surface density of $-\mathrm{NH}_{2}$ groups of aminederived $\mathrm{SiO}_{2}-\mathrm{MNP}$ could be determined quantitatively to be $1.19 \pm 0.02 \mu \mathrm{mole} / \mathrm{mg}$ particle. The abundance of $-\mathrm{NH}_{2}$ groups hanging from the particle surface can facilitate the immobilization of tPA by glutaraldehyde-mediated imide bond formation. The size of amine-derived $\mathrm{SiO}_{2}-\mathrm{MNP}$ remains unchanged at $191.0 \pm 5.1 \mathrm{~nm}$ (polydispersive index $=0.195$ )

The FTIR spectra of different NPs are presented in Figure 3D. For $\mathrm{Fe}_{3} \mathrm{O}_{4}-\mathrm{MNP}$, an absorption band at $572 \mathrm{~cm}^{-1}$ corresponding to the $\mathrm{Fe}-\mathrm{O}-\mathrm{Fe}$ vibration relates to the magnetite phase. The peak at $1632 \mathrm{~cm}^{-1}$ represents $\mathrm{N}-\mathrm{H}$ bond formation during the chemical coprecipitation of $\mathrm{Fe}^{+2}$ and $\mathrm{Fe}^{+3}$ salts induced by the addition of $\mathrm{NH}_{4} \mathrm{OH}$ base. For $\mathrm{SiO}_{2}-\mathrm{MNP}$ the existence of the characteristic peaks at 792,967 , and $1084 \mathrm{~cm}^{-1}$, due to the symmetric and asymmetric stretching vibration of framework and terminal $\mathrm{Si}-\mathrm{O}-$ groups, is direct evidence to verify the formation of the silica shell. The characteristic $\mathrm{Fe}-\mathrm{O}-\mathrm{Fe}$ peak shifts from $572 \mathrm{~cm}^{-1}$ to $589 \mathrm{~cm}^{-1}$ in the spectrum of $\mathrm{SiO}_{2}-\mathrm{MNP}$, indicating that the silica shell is linked to the surface of the $\mathrm{Fe}_{3} \mathrm{O}_{4}-\mathrm{MNP}$ by $\mathrm{Fe}-\mathrm{O}-\mathrm{Si}$ chemical bonds. Also, the peak at $1551 \mathrm{~cm}^{-1}$ corresponds with the $-\mathrm{NH}_{2}$ characteristic peak in amine-derived $\mathrm{SiO}_{2}-\mathrm{MNP}$. All diffraction peaks of the XRD patterns of the prepared NP can be easily indexed to a pure cubic phase of $\mathrm{Fe}_{3} \mathrm{O}_{4}$ (JCPDS No 65-3107) (Figure 3E). The characteristic peaks at $2 \theta=30.2^{\circ}, 35.4^{\circ}, 43.1^{\circ}, 53.2^{\circ}, 56.9^{\circ}$, and $62.5^{\circ}$ for pure $\mathrm{Fe}_{3} \mathrm{O}_{4}-\mathrm{MNP}$, which represent corresponding indices (220), (311), (400), (422), (511), and (440), are also observed for $\mathrm{SiO}_{2}$-MNP. Surface coating $\mathrm{Fe}_{3} \mathrm{O}_{4}$-MNPs with silica thus did not lead to their phase change. It should 

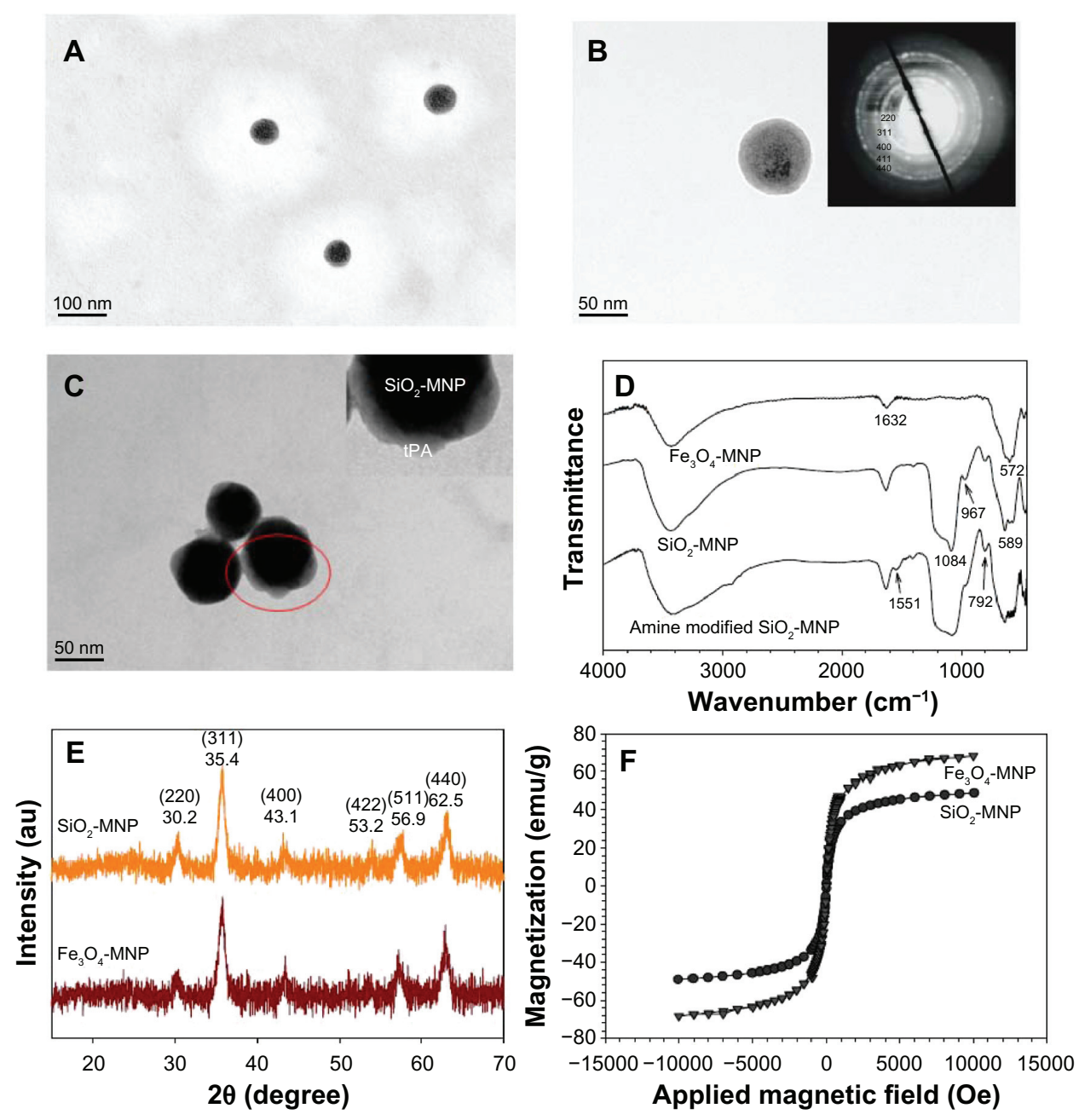

Figure 3 Transmission electron microscope images of ( $\mathbf{A}$ and $\mathbf{B})$ silica-coated magnetic nanoparticle $\left(\mathrm{SiO}_{2}-\mathrm{MNP}\right)$ and $(\mathbf{C})$ tissue plasminogen activator (tPA) bound to $\mathrm{SiO}{ }_{2}-$ $\mathrm{MNP}\left(\mathrm{SiO}_{2}-\mathrm{MNP}\right.$-tPA) after staining with phosphotungstic acid. Characterization of superparamagnetic iron oxide magnetic nanoparticle (Fe $\left.\mathrm{O}_{4}-\mathrm{MNP}\right)$ and $\mathrm{SiO}{ }_{2}-\mathrm{MNP}$ with (D) Fourier transform infrared spectroscopy analysis, (E) X-ray diffraction patterns, and (F) superconducting quantum interference device magnetization curves.

Notes: $(\mathbf{A})$ Magnification $=100,000$, bar $=100 \mathrm{~nm}$; $(\mathbf{B}$ and $\mathbf{C})$ magnification $=300,000$, bar $=50 \mathrm{~nm}$. Insert in $(\mathbf{B})$ is electron diffraction pattern; insert in $(\mathbf{C})$ is a blowup of the circled area.

be noted that only minor broad reflection at low $2 \theta$ values $\left(20^{\circ} \sim 30^{\circ}\right)$, originating from the amorphous silica matrix, appears in $\mathrm{SiO}_{2}-\mathrm{MNP}$ XRD patterns after silica coating due to the thin silica coating layer (Figure 3B). ${ }^{38}$ The average particle size calculated using the Debye-Scherrer formula from the reflection peak of (311) is about $13.9 \mathrm{~nm},{ }^{39}$ consistent with the result measured from the TEM images. The results of SQUID analysis at room temperature indicate a saturation magnetization value of $48.9 \mathrm{emu} / \mathrm{g}$ for $\mathrm{SiO}_{2}-\mathrm{MNP}$, which is lower than that of bare $\mathrm{Fe}_{3} \mathrm{O}_{4}-\mathrm{MNP}(68.3 \mathrm{emu} / \mathrm{g})$ due to the coated shell (Figure 3F). This can be explained by considering the diamagnetic contribution of the silica shell surrounding the magnetite, which was also observed in a previous study. ${ }^{40}$ Generally, the saturation magnetization would decrease when the particle surface was covered by coating materials. The high magnetization value will greatly enhance the ability for magnetic guidance and complete magnetic blood clot penetration by the NP. ${ }^{41}$ From the magnetization curve, the remanence (residue magnetization) and coercive force (the applied field that reduces magnetization to zero) were zero, and there was no magnetic hysteresis loop observed, indicating the characteristic superparamagnetic behavior.

Figure 4A shows the TGA curves of MNPs. All samples show an initial small mass loss at temperatures below $200^{\circ} \mathrm{C}$ due to desorption of adsorbed water and $\mathrm{CO}_{2}$. At temperatures above $200^{\circ} \mathrm{C}$, there is negligible weight loss for $\mathrm{Fe}_{3} \mathrm{O}_{4}$-MNP with no observable peak temperature for the highest weight loss in the differential weight loss curve (Figure 4B). In contrast, $\mathrm{SiO}_{2}-\mathrm{MNP}$ samples showed distinct behavior due to the decomposition of functional groups. Peak temperatures at $345^{\circ} \mathrm{C}$ and $310^{\circ} \mathrm{C}$ were found for $\mathrm{SiO}_{2}-\mathrm{MNP}$ and aminederived $\mathrm{SiO}_{2}-\mathrm{MNP}$, respectively, due to decomposition of 
A

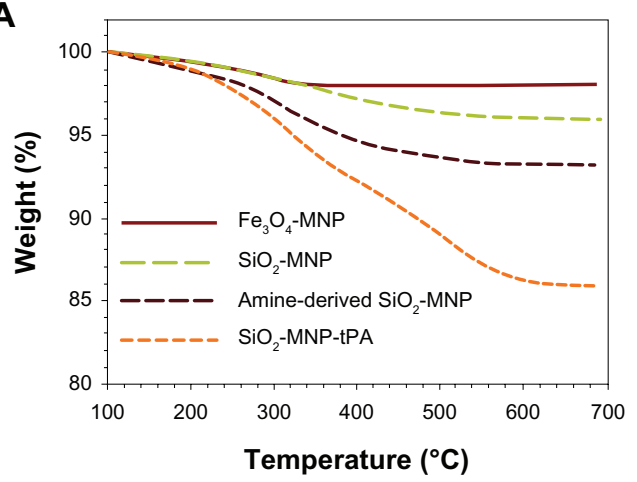

B

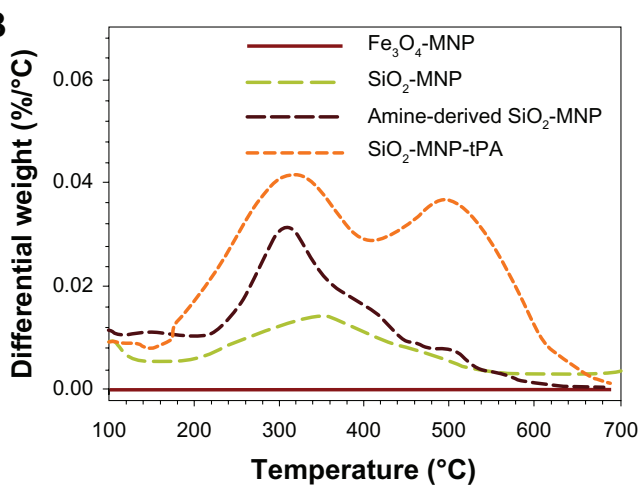

Figure 4 Thermogravimetric analysis of superparamagnetic iron oxide magnetic nanoparticle $\left(\mathrm{Fe}_{3} \mathrm{O}_{4}-\mathrm{MNP}\right)$, silica-coated magnetic nanoparticle (SiO $\left.-\mathrm{MNP}\right)$, $\mathrm{SiO}{ }_{2}-\mathrm{MNP}_{2}$ surface modified with 3-aminopropyltriethoxysilane (amine-derived $\mathrm{SiO}_{2}-\mathrm{MNP}$ ), and tissue plasminogen activator (tPA) bound to $\mathrm{SiO} \mathrm{O}_{2}-\mathrm{MNP}\left(\mathrm{SiO} \mathrm{O}_{2}-\mathrm{MNP}\right.$-tPA).

the organic parts (hydroxyl and propylamine groups) from the NP surface (Figure 1). The mass loss of amine-derived $\mathrm{SiO}_{2}-\mathrm{MNP}$ is $6.2 \mathrm{wt} \%$ (Figure $4 \mathrm{~A}$ ). Under the assumption that all the ethoxy groups were eliminated during silica formation and that only the organic part of the linker (propylamine) contributes to the mass loss for amine-derived $\mathrm{SiO}_{2}$-MNP, this weight loss corresponds to $1.07 \mu \mathrm{mol} / \mathrm{mg}$, which is in fairly good agreement with the value obtained from the surface density of $-\mathrm{NH}_{2}$ groups $(1.19 \mu \mathrm{mol} / \mathrm{mg})$. The cytotoxicity of $\mathrm{SiO}_{2}-\mathrm{MNP}$ on $3 \mathrm{~T} 3$ fibroblast cells was examined using the MTT method for cell proliferation and the LDH assay for cell damage. The MTT assay is a simple nonradioactive colorimetric assay to measure the level of cell viability. The LDH assay is a convenient method to evaluate cell damage from the release of LDH from lysed cells. Figure 5 shows that $\mathrm{SiO}_{2}-\mathrm{MNP}$ mediated very low cytotoxicity within the concentration range studied. There is no statistical difference in $\mathrm{OD}_{570}$ or $\mathrm{OD}_{490}$ from the control (3T3 cells without contacting $\mathrm{SiO}_{2}$-MNP) when $3 \mathrm{~T} 3$ cells were exposed to different concentrations of $\mathrm{SiO}_{2}-\mathrm{MNP}(P<0.05)$. Since the threshold cytotoxic concentration of MNP has been reported to be within our testing range, ${ }^{42}$ the in vitro biocompatibility test indicated that $\mathrm{SiO}_{2}$-MNP elicited no cytotoxicity.

Figure 6 shows the T2-weighted MRI images of B6 mice after tail vein injection of PBS (control) or $10 \mathrm{mg} / \mathrm{mL}$ $\mathrm{SiO}_{2}$-MNP suspended in PBS. After intravenous injection, the liver was darkened significantly for mice administrated with $\mathrm{SiO}_{2}$-MNP in comparison with that of control, indicating that $\mathrm{SiO}_{2}$-MNP could be used as an imaging agent and visualized in MRI.

\section{Preparation and properties of tPA immobilized to silica-coated magnetic nanoparticles}

One of the major challenges of enzyme immobilization to MNP is the loss of enzyme activity after immobilization. ${ }^{43}$ Covalent immobilization of tPA to $\mathrm{SiO}_{2}$-MNP may potentially involve amino acids necessary for substrate recognition or
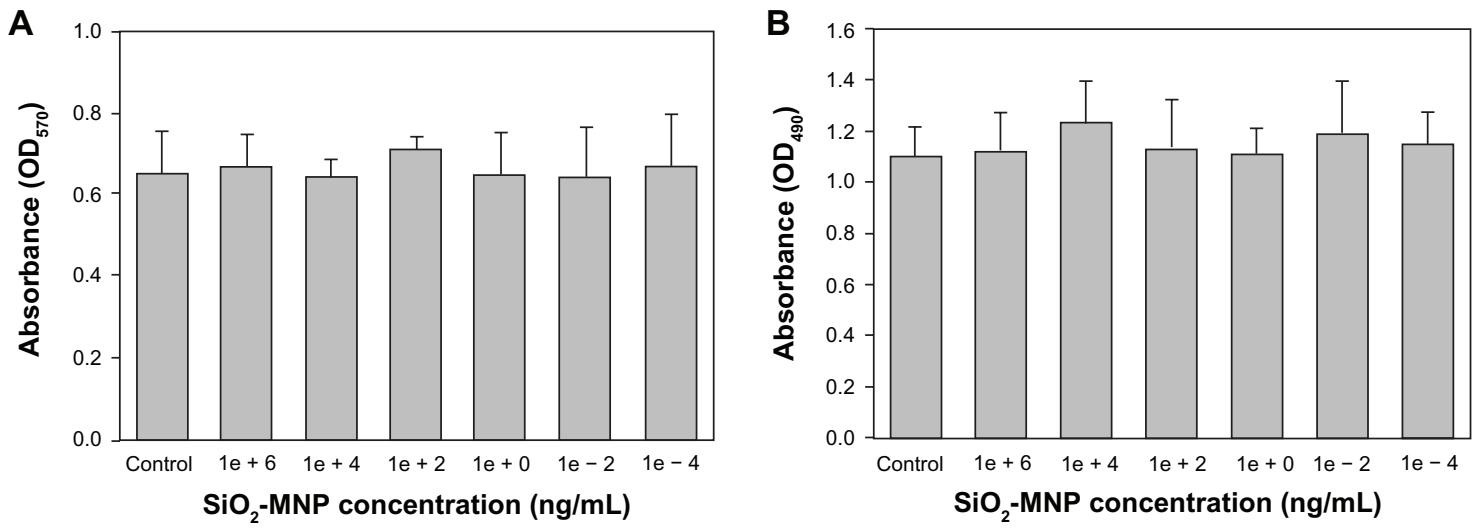

Figure 5 Cytotoxicity analysis of silica-coated magnetic nanoparticles ( $\left.\mathrm{SiO}_{2}-\mathrm{MNP}\right)$ by 3-(4,5-dimethylthiazol-2-yl)-2,5-diphenyl-tetrazolium bromide (MTT) (A) and lactate

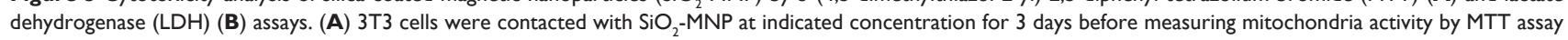
at $570 \mathrm{~nm}\left(\mathrm{OD}_{570}\right)$. (B) $3 \mathrm{~T} 3$ cells were contacted with $\mathrm{SiO}_{2}-\mathrm{MNP}$ at indicated concentration for I day before measuring released $\mathrm{LDH}_{\mathrm{H}}$ concentration at $490 \mathrm{~nm}\left(\mathrm{OD}{ }_{490}\right)$. Note: $3 \mathrm{~T} 3$ cells without contacting $\mathrm{SiO}_{2}-\mathrm{MNP}$ were used as the control. 


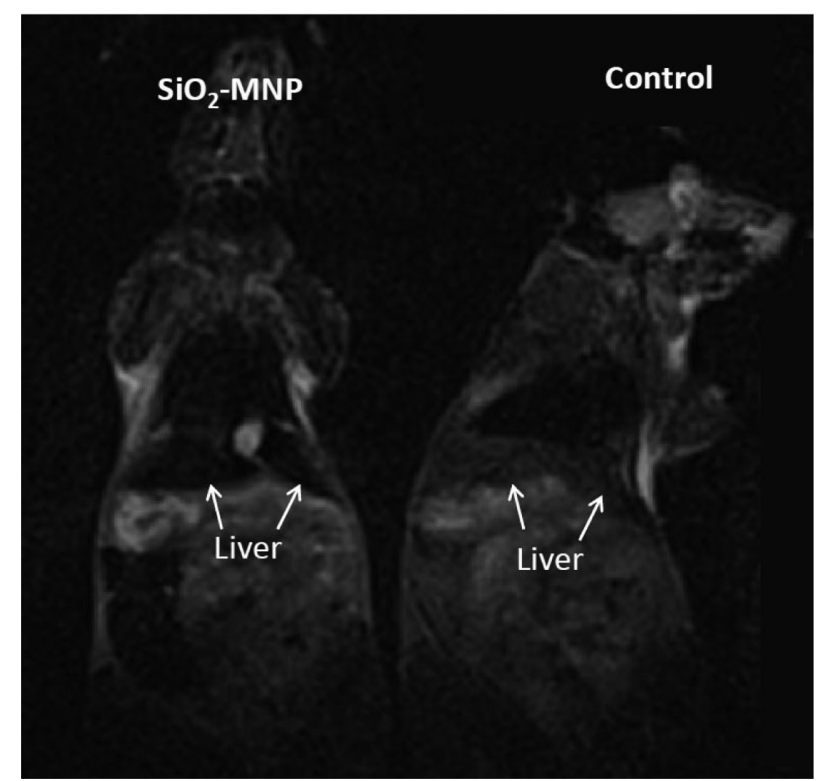

Figure 6 In vivo T2-weighted magnetic resonance images of silica-coated magnetic nanoparticles $\left(\mathrm{SiO}_{2}-\mathrm{MNP}\right)$ in mice 2 hours after injection of phosphate-buffered saline (PBS) (control) or $\mathrm{SiO}_{2}-\mathrm{MNP}$ in PBS.

catalytic activity, which will result in loss of the enzyme activity after immobilization. The effect of the amount of tPA used for immobilization was studied and the results are shown in Figure 7 . The protein loading efficiency and the activity retention remain $>95 \%$ up to $0.3 \mathrm{mg}$ tPA, which subsequently decrease at higher tPA loadings. The immobilized tPA activity per $\mathrm{mg}$ of $\mathrm{SiO}_{2}-\mathrm{MNP}$ will be important in order to use the least amount of NP during in vivo application. This value also reaches a plateau at around $0.5 \mathrm{mg}$ tPA. The optimum drug loading is therefore reached when $0.5 \mathrm{mg}$ tPA is reacted with $5 \mathrm{mg} \mathrm{SiO}{ }_{2}-\mathrm{MNP}$, by which $94 \%$ tPA is attached to the carrier with $86 \%$ retention of its amidolytic activity.

In this study, tPA activator was immobilized to aminederived $\mathrm{SiO}_{2}-\mathrm{MNP}$ by a two-step process using GA as

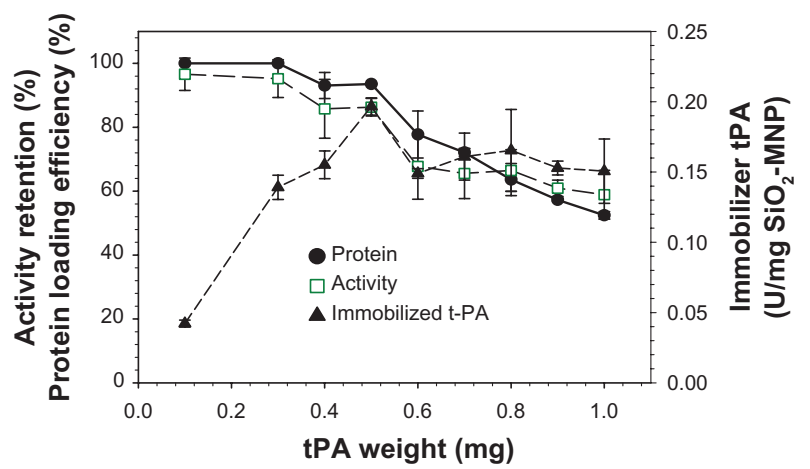

Figure 7 The effects of the amount of tissue plasminogen activator (tPA) added during immobilization on the protein loading efficiency and activity retention of tPA immobilized to silica-coated magnetic nanoparticles $\left(\mathrm{SiO}_{2}-\mathrm{MNP}\right)(5 \mathrm{mg})$. a crosslinking agent. Previously, tPA was immobilized to polyacrylic acid-coated MNP by using carbodiimide-mediated amide bond formation between carboxylic acid groups of polyacrylic acid and amine groups of tPA. ${ }^{31}$ For amine-derived $\mathrm{SiO}_{2}$-MNP, imide bond formation between tPA and $\mathrm{SiO}_{2}$-MNP could be achieved with GA or genipin. Although genipin may be preferable to reduce the associated toxicity of GA, it may not equate to GA's ability to immobilize and promote the formation of imide bonds between the aldehyde groups of GA and amine groups of $\mathrm{SiO}_{2}$-MNP or tPA. ${ }^{44}$ Considering GA as a crosslinking agent in clinical application, bioprostheses made of GA-treated bovine pericardium or porcine heart valve tissues have been used for more than 20 years. ${ }^{45}$ A recent study used $\mathrm{N}$-hydroxysulfosuccinimide and tresyl chloride to conjugate tPA to MNP. However, the protein loading efficiency (63\%) and the activity retention (45\%) are much lower than those in current study using GA. ${ }^{46}$

Due to the selective staining of silica and protein with PTA, tPA molecules (gray region) could be observed to attach to the surface of $\mathrm{SiO}_{2}-\mathrm{MNP}$ (black region) (Figure $3 \mathrm{C}$ ). TGA analysis of $\mathrm{SiO}_{2}-\mathrm{MNP}$-tPA indicates additional weight loss after conjugating tPA and a new peak temperature at $500^{\circ} \mathrm{C}$ (Figure 4B), which can be assigned to the decomposition of tPA protein moiety. The weight percentage of tPA in $\mathrm{SiO}_{2}$-MNP-tPA preparation could be calculated to be $8.3 \%$ from the difference between the weight loss of amine-derived $\mathrm{SiO}_{2}-\mathrm{MNP}$ and $\mathrm{SiO}_{2}-\mathrm{MNP}$-tPA (Figure 4A), which could be compared with $8.6 \%$ calculated from protein assay.

From fibrin clot lysis assay, the fibrinolytic activity of $\mathrm{SiO}_{2}$-MNP-tPA is not different from free tPA $(P<0.05)$ for concentrations up to $1 \mathrm{mg} / \mathrm{mL}$ tPA, suggesting that all fibrinolytic activity of tPA could be preserved after immobilization to $\mathrm{SiO}_{2}-\mathrm{MNP}$ (Figure 8). Covalent binding of tPA to $\mathrm{SiO}_{2}-\mathrm{MNP}$ hence fully preserved its fibrinolytic activity, which is critical for effective thrombolysis in vivo.

To provide a readily available tPA formulation for immediate thrombolysis application, it is important that tPA immobilized to $\mathrm{SiO}_{2}-\mathrm{MNP}$ could be stored in PBS and preserve a reasonable residue activity when needed. Thus, the storage stability of free tPA and $\mathrm{SiO}_{2}-\mathrm{MNP}$-tPA was determined by measuring the residual activity in $\mathrm{PBS}$ at $4^{\circ} \mathrm{C}$ (Figure 9). After 72 days, the residual activities are $43.6 \%$ and $91.0 \%$ for free and immobilized t-PA, respectively. The activity decay could be modeled with first-order enzyme inactivation kinetics. ${ }^{47}$ The inactivation rate constants $\left(\mathrm{k}_{\mathrm{d}}\right)$ determined from the data are $1.092 \times 10^{-2} \mathrm{~d}^{-1}\left(\mathrm{r}^{2}=0.995\right)$ 


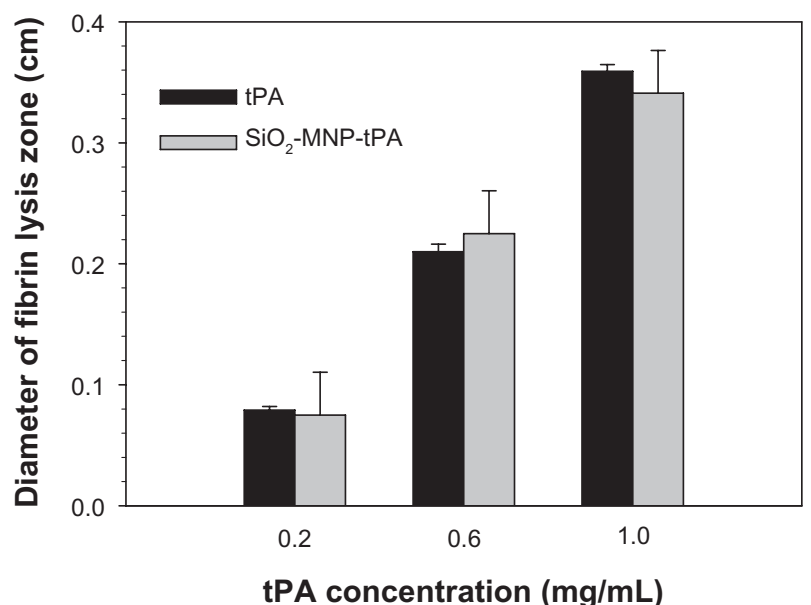

Figure 8 Fibrinolytic activities of tissue plasminogen activator (tPA) and tPA bound to silica-coated magnetic nanoparticles $\left(\mathrm{SiO}_{2}-\mathrm{MNP}\right.$-tPA) by fibrin clot lysis assays.

and $1.152 \times 10^{-3} \mathrm{~d}^{-1}\left(\mathrm{r}^{2}=0.933\right)$ for free and immobilized tPA, respectively. The calculated half-life $\left(\ln 2 / \mathrm{k}_{\mathrm{d}}\right)$ is thus $63.5 \mathrm{~d}$ and $601.6 \mathrm{~d}$. In general, immobilization of enzyme with MNP as support material has been considered as one of the efficient methods to improve enzyme stability. ${ }^{48}$ In the current study, the stability of tPA in solution at $4{ }^{\circ} \mathrm{C}$ was enhanced 9.5-fold as a result of binding to $\mathrm{SiO}_{2}-\mathrm{MNP}$. Possible mechanisms leading to enhanced storage stability of tPA could be ascribed to the restriction of the conformation change of the drug after covalent binding with $\mathrm{SiO}_{2}-\mathrm{MNP}$, thus preventing distortion and activity loss of the enzyme molecule. ${ }^{49,50}$ The increased storage stability of bound tPA is crucial to extend the period during which it could fully exert its therapeutic effects in vivo when needed.

However, it is not known whether MNP-bound tPA may exert a prolonged half-life in vivo compared with that

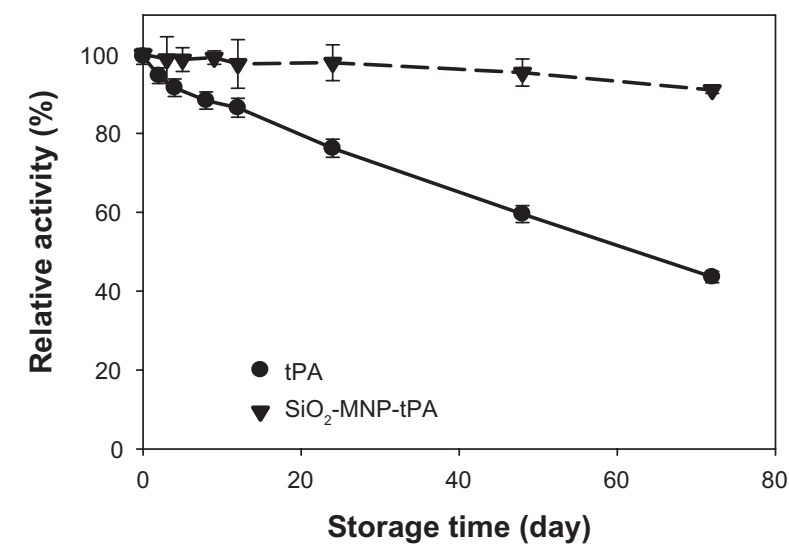

Figure 9 Storage stability of tissue plasminogen activator (tPA) and tPA bound to silica-coated magnetic nanoparticles $\left(\mathrm{SiO}_{2}-\mathrm{MNP}-\mathrm{tPA}\right)$.

Notes: The residual amidolytic activity after incubation in phosphate-buffered saline at $4^{\circ} \mathrm{C}$ for time indicated was determined by chromogenic substrate assay. Relative activity was defined as percentage activity of $\mathrm{tPA}$ and $\mathrm{SiO}_{2}-\mathrm{MNP}$-tPA, respectively, at day 0 . of free tPA. To simulate in vivo conditions, the operation stability was determined from the residual fibrinolytic activity of tPA after incubating the drug in whole blood for a specific time (Figure 10). The diameter of fibrin lysis zone for free and immobilized tPA showed statistical difference if the incubation time in blood is longer than 5 minutes. At 45 minutes' incubation time in blood, the diameter is $0.42 \mathrm{~cm}$ and $0.15 \mathrm{~cm}$ for free tPA and $\mathrm{SiO}_{2}-\mathrm{MNP}$-tPA, respectively, corresponding to a 2.8 -fold increase in stability in blood using immobilized tPA. Results of previous studies have shown that coupling tPA to RBCs increased its intravascular life span compared with soluble tPA. ${ }^{51}$ One possible explanation for this surprising result is that coupling to RBCs renders tPA less susceptible to plasma tPA inhibitors, ${ }^{52}$ including the most physiologically relevant plasminogen activator inhibitor 1 (PAI-1). Further studies affirm the greater fibrinolytic potency of bound tPA compared with soluble tPA in mouse blood, and indicate that coupling to RBCs protects tPA against physiological and pathological concentrations of PAI- $1,{ }^{53}$ and inhibition by other serpins ( $\alpha_{2}$-macroglobulin and $\alpha_{1}$-antitrypsin). As the interaction of tPA and PAI-1 may be stabilized through salt bridges formed between cationic amino acid in TPA and anionic residues in PAI- $1,{ }^{54}$ the authors propose that the protection is due to charge-mediated masking of vulnerable sites on tPA molecules by the negatively charged components of glycocalyxon on the surface of RBCs. This is consistent with the negative surface potential $(-27.0 \pm 0.4 \mathrm{mV})$ of $\mathrm{SiO}_{2}-\mathrm{MNP}$ due to the presence of negatively charged surface silanol groups. Sensitivity to inhibitors is one of the factors that may control the longevity of $\mathrm{SiO}_{2}$-MNP-tPA activity in vivo.

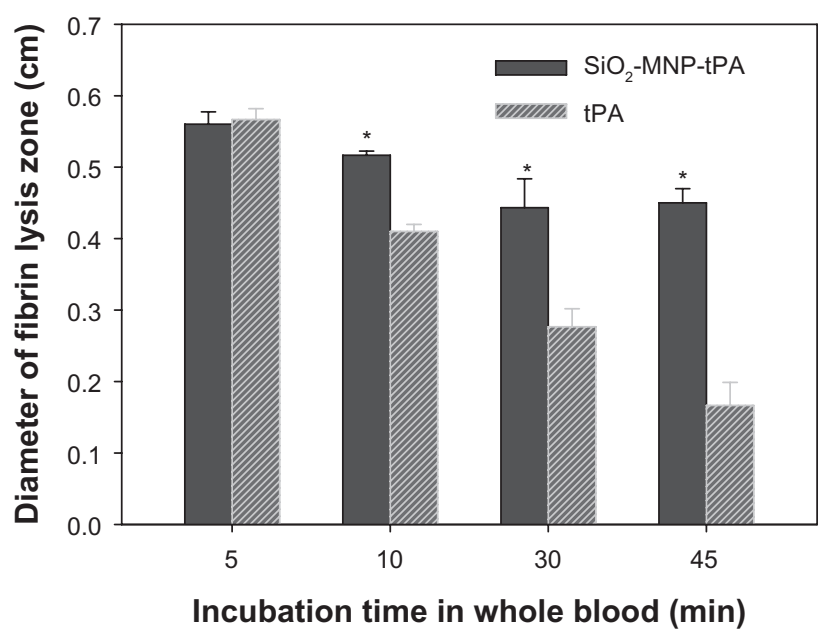

Figure 10 Operation stability of tissue plasminogen activator (tPA) and tPA bound to silica-coated magnetic nanoparticles ( $\mathrm{SiO}_{2}-\mathrm{MNP}$-tPA).

Notes: The residual fibrinolytic activity after incubation in blood at $37^{\circ} \mathrm{C}$ for time indicated was determined by fibrin clot lysis assay. ${ }^{* P}<0.05$ compared with corresponding tPA value. 
Table I Hematological measurements in rats treated with $0.1 \mathrm{~mL}$ phosphate-buffered saline (PBS) (control), tissue plasminogen activator (tPA) in PBS ( $1 \mathrm{mg} / \mathrm{mL}), 10 \mathrm{mg} / \mathrm{mL}$ silica-coated magnetic nanoparticle $\left(\mathrm{SiO}_{2}-\mathrm{MNP}\right)$ in PBS, or $10 \mathrm{mg} / \mathrm{mL} \mathrm{SiO}_{2}-\mathrm{MNP}_{\text {-tPA in }}$ PBS (equivalent to I $\mathrm{mg} / \mathrm{mL}$ tPA)

\begin{tabular}{llllll}
\hline Treatment & RBC $\left(10^{6} / \mu \mathrm{L}\right)$ & WBC $\left(10^{3} / \mu \mathrm{L}\right)$ & Platelet $\left(10^{3} / \mu \mathrm{L}\right)$ & HGB $(\mathrm{g} / \mathrm{dL})$ & HCT $(\%)$ \\
\hline Control & $9.4 \pm 0.5$ & $5.2 \pm 0.2$ & $1054 \pm 50$ & $12.1 \pm 0.6$ & $48.9 \pm 1.4$ \\
tPA & $8.9 \pm 0.4$ & $5.0 \pm 0.3$ & $850 \pm 29^{*}$ & $11.6 \pm 0.5$ & $47.2 \pm 1.0$ \\
$\mathrm{SiO}_{2}$-MNP & $9.1 \pm 0.3$ & $6.9 \pm 0.1^{*}$ & $804 \pm 48^{*}$ & $11.7 \pm 0.7$ & $49.8 \pm 1.3$ \\
$\mathrm{SiO}_{2}$-MNP-tPA & $9.2 \pm 0.4$ & $5.3 \pm 0.3$ & $1100 \pm 76$ & $11.8 \pm 0.4$ & $48.2 \pm 1.2$ \\
\hline
\end{tabular}

Notes: Concentrations of red blood cells (RBC), white blood cells (WBC), platelets, hemoglobin (HGB), and hematocrit (HCT) were determined by automated hematology system (values presented as mean \pm standard error). $* P<0.05$ compared with control.

For blood compatibility, the results of hematological analysis are illustrated in Table 1. The platelet counts of tPA and $\mathrm{SiO}_{2}-\mathrm{MNP}$ were different from the control $(P<0.05)$ WBCs of $\mathrm{SiO}_{2}-\mathrm{MNP}$ were also elevated $(P<0.05)$. However, other counts of RBCs, WBCs, hemoglobin, and hematocrit were not different among groups. Target thrombolysis with $\mathrm{SiO}_{2}$-MNP-tPA will therefore be well suited for in vivo applications.

\section{Blood clot lysis and micro-CT analysis}

The efficacy of thrombolysis by $\mathrm{SiO}_{2}$-MNP-tPA was studied with an ex vivo intravascular thrombolysis model. The time to blood flow from capillary is shown in Figure 11. Runs with $\mathrm{SiO}_{2}$-MNP (with or without magnet) show no difference in blood flow time from that of control (blood only). The thrombolysis efficacy of free and bound tPA in blood was compared using the same tPA drug dosage $(0.2 \mathrm{mg} / \mathrm{mL})$. Although the activity of $\mathrm{SiO}_{2}$-MNP-tPA is $86 \%$ that of free

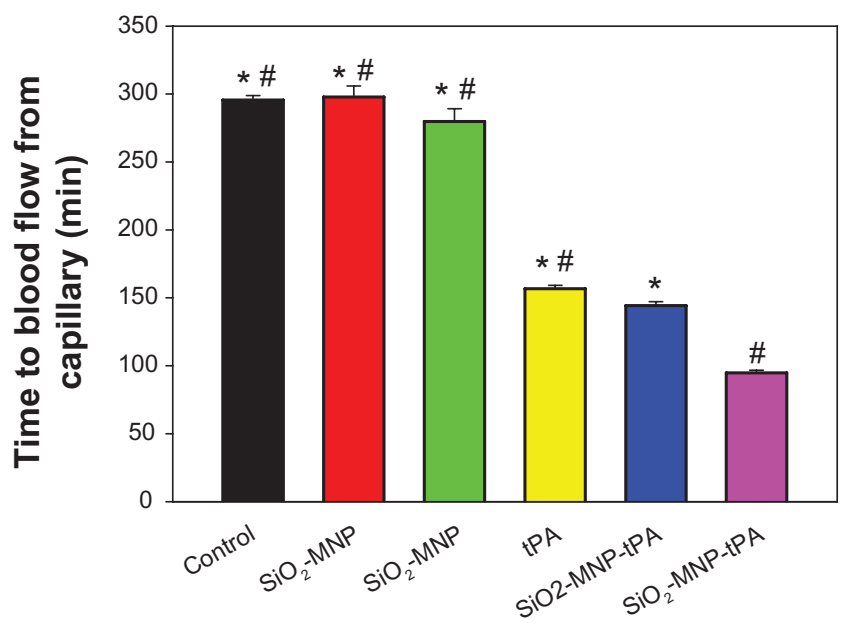

Magnet

Figure I I The efficacy of thrombolysis studied with an ex vivo thrombolysis model as shown in Figure 2.

Notes: The time to blood flow from capillary with or without magnet for magnetic guidance is shown. $* P<0.05$ compared with tissue plasminogen activator bound to silica-coated magnetic nanoparticles $\left(\mathrm{SiO}_{2}-\mathrm{MNP}\right.$-tPA) with magnet; ${ }^{\# P}<0.05$ compared with $\mathrm{SiO}_{2}-$ MNP-tPA without magnet.
tPA (Figure 7), the blood flow times are 157 and 144 minutes for free tPA and $\mathrm{SiO}_{2}$-MNP-tPA, respectively. This improvement in thrombolysis ability is consistent with the enhanced fibrinolytic activity retention in whole blood for the bound drug (Figure 9). Magnetic guidance can further reduce the blood flow time of $\mathrm{SiO}_{2}$-MNP-tPA to 95 minutes, which is $66 \%$ that of the run without magnetic targeting and $60 \%$ that of the free tPA run. Magnetic targeting delivery of $\mathrm{SiO}_{2}$-MNP-tPA can therefore effectively shorten the thrombolysis time compared with the conventional treatment with free tPA under the same drug dosage. Alternatively, a reduced dosage of tPA could be used in vivo to reach the same thrombolysis effect by delivering $\mathrm{SiO}_{2}$-MNP-tPA under magnetic guidance, which can prevent the hemorrhagic side effect of tPA.

Micro-CT studies were used to provide semiquantitative estimates about the spatial distribution of MNP within a whole blood clot (Figure 12). Magnetic targeting was employed by placing a magnet below the clot at the tube bottom. Exposure of the clots to $\mathrm{SiO}_{2}-\mathrm{MNP}$ with or without magnetic fields showed no difference in penetration depth with minimum downward movement (Figure 12A and B). In contrast, $\mathrm{SiO}_{2}-\mathrm{MNP}$-tPA delineated a considerable increase in clot penetration from the passage trajectories of MNP (Figure 12C). Similar to previous studies when blood clots were exposed to tPA alone, ${ }^{39} \mathrm{SiO}_{2}$-MNP-tPA penetration depth and lysis zone are restricted to the top layer of the thrombus due to limited drug delivery into the thrombus with the presence of tight fibrin meshwork. ${ }^{55-57}$ In contrast, the combination of $\mathrm{SiO}_{2}$-MNP-tPA and a magnetically driven force delineated a substantial increase in clot penetration (Figure 12D). The frontal shape was not flat in the image of micro-CT under magnetic guidance with the nonuniformity of external magnetic field in contrast to without magnetic field where a flat front was observed with the continued lysis of clots with tPA bound to the NPs. These experiments provided direct evidence that not only tPA bound to $\mathrm{SiO}_{2}$-MNP exerted thrombolysis activity but also the exposure of the thrombus 


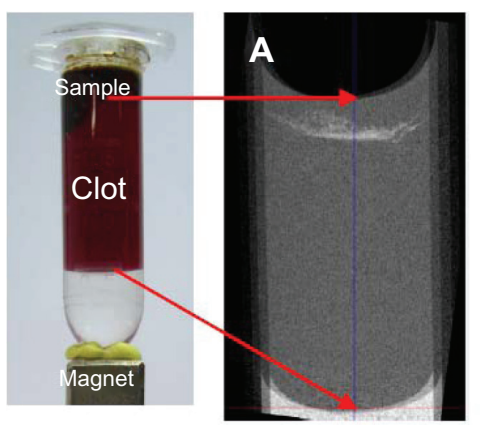

tPA

Magnet
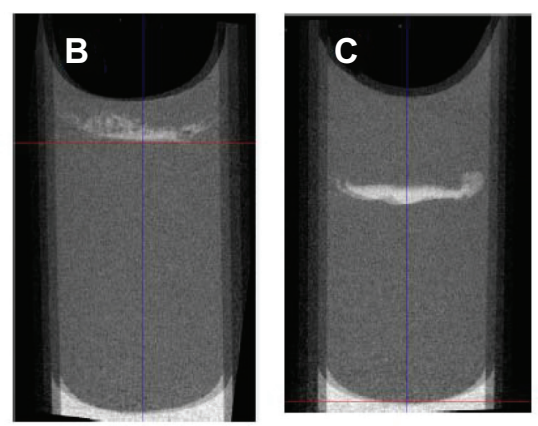

$+$

-

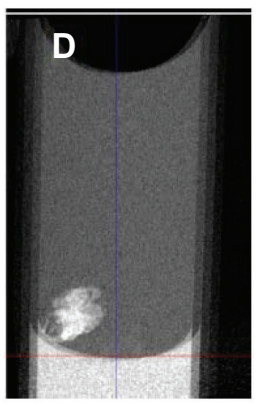

$+$

$+$

Figure 12 Microcomputed tomography imaging of the penetration of silica-coated magnetic nanoparticles into blood clot with or without immobilized tissue plasminogen activator (tPA) and with or without a magnet at the clot bottom for magnetic guidance.

Note: The red arrows indicate imaging boundaries.

to magnetic fields resulted in enhanced penetration of MNP into the clot, supporting the improved clot lysis efficacy of $\mathrm{SiO}_{2}$-MNP-tPA under magnetic guidance (Figure 11).

\section{Conclusion}

Biocompatible $\mathrm{SiO}_{2}-\mathrm{MNP}$ could be prepared and used for covalent immobilization of tPA with a high protein loading efficiency and activity retention. The results presented herein demonstrate the characteristic of $\mathrm{SiO}_{2}$-MNP to make it useful as a magnetic targeting drug carrier. By conjugating tPA to an $\mathrm{SiO}_{2}$-MNP surface, a new form of thrombolytic drug potentially useful for treatment of thrombus was achieved and is expected to improve clinical thrombolytic therapy.

\section{Acknowledgments}

Financial support from National Science Council (NSC992120-M-182-001), National Health Research Institute (NHRI-EX101-9937EI), Department of Health (DOH101TD-PB-111-TM009), and Chang Gung Memorial Hospital was highly appreciated.

\section{Disclosure}

The authors report no conflicts of interest in this work.

\section{References}

1. Pankhurst QA, Connolly J, Jones SK, Dobson J. Applications of magnetic nanoparticles in biomedicine. J Phys D Appl Phys. 2003;36: R167-R181.

2. Gupta AK, Gupta M. Synthesis and surface engineering of iron oxide nanoparticles for biomedical applications. Biomaterials. 2005;26: 3995-4021.

3. Sun C, Lee JSH, Zhang MQ. Magnetic nanoparticles in MR imaging and drug delivery. Adv Drug Deliv Rev. 2008;60:1252-1265.

4. Figuerolaa A, Di Coratob R, Mannaa L, Pellegrinoa T. From iron oxide nanoparticles towards advanced iron-based inorganic materials designed for biomedical applications. Pharmacol Res. 2010;62:126-143.
5. Gan SY, Chow M. Carboxyl group $\left(-\mathrm{CO}_{2} \mathrm{H}\right)$ functionalized ferromagnetic iron oxide nanoparticles for potential bio-applications. $J$ Mater Chem. 2004;14:2781-2786.

6. Sun S, Ma M, Qiu N, et al. Affinity adsorption and separation behaviors of avidin on biofunctional magnetic nanoparticles binding to iminobiotin. Colloid Surface B. 2011;88:246-253.

7. Kaushik A, Khan R, Solanki PR, et al. Iron oxide nanoparticles-chitosan composite based glucose biosensor. Biosens Bioelectron. 2008;24: 676-683.

8. Sun J, Zhou SB, Hou P, et al. Synthesis and characterization of biocompatible $\mathrm{Fe}_{3} \mathrm{O}_{4}$ nanoparticles. J Biomed Mater Res. 2006;80A: 333-341.

9. Butterworth MD, Illum L, Davis SS. Preparation of ultrafine silicaand PEG-coated magnetite particles. Colloid Surface B. 2001;179: 93-102.

10. Fang C, Zhang M. Multifunctional magnetic nanoparticles for medical imaging applications. J Mater Chem. 2009;19:6258-6266.

11. Kohler N, Fryxell GE, Zhang M. A bifunctional poly(ethylene glycol) silane immobilized on metallic oxide-based nanoparticles for conjugation with cell targeting agents. J Am Chem Soc. 2004;126:7206-7011.

12. Barbe C, Bartlett J, Kong L, Finnie K, Lin HQ, Larkin M, et al. Silica particles: a novel drug-delivery system. Adv Mater. 2004;16: 1959-1966.

13. Jain TK, Roy I, De TK, Maitra AN. Nanometer silica particles encapsulating active compounds: A novel ceramic drug carrier. $\mathrm{J} \mathrm{Am} \mathrm{Chem}$ Soc. 1998;120:11092-11095.

14. Chen FH, Gao Q, Ni JZ. The grafting and release behavior of doxorubincin from $\mathrm{Fe}_{3} \mathrm{O}_{4} @ \mathrm{SiO}_{2}$ core-shell structure nanoparticles via an acid cleaving amide bond: the potential for magnetic targeting drug delivery. Nanotechnology. 2008;19:165103.

15. Arruebo M, Galán M, Navascués N, et al. Development of magnetic nanostructured silica-based materials as potential vectors for drugdelivery applications. Chem Mater. 2006;18:1911-1919.

16. Zhou L, Wu W, Caruntu D, et al. Synthesis of porous magnetic hollow silica nanospheres for nanomedicine application. J Phys Chem C. 2007; 111:17473-17477.

17. Santra S, Tapec R, Theodoropoulou N, Dobson J, Hebard A, Tan WH. Synthesis and characterization of silica-coated iron oxide nanoparticles in microemulsion: the effect of nonionic surfactants. Langmuir. 2001;17:2900-2906.

18. Yi DK, Selvan ST, Lee SS, Papaefthymiou GC, Kundaliya D, Ying JY. Silica-coated nanocomposites of magnetic nanoparticles and quantum dots. J Am Chem Soc. 2005;127:4990-4991.

19. Li C, Ma C, Wang F, et al. Preparation and biomedical applications of core-shell silica/magnetic nanoparticle composites. J Nanosci Nanotechnol. 2012;12:2964-2972. 
20. Yang CQ, Wang G, Lu ZY, Sun J, Zhuang JQ, Yang WS. Effect of ultrasonic treatment on dispersibility of $\mathrm{Fe}_{3} \mathrm{O}_{4}$ nanoparticles and synthesis of multi-core $\mathrm{Fe}_{3} \mathrm{O}_{4} / \mathrm{SiO}_{2}$ core/shell nanoparticles. J Mater Chem. 2005;15:4252-4257.

21. Lu ZY, Wang G, Zhuang JQ, Yang WS. Effects of the concentration of tetramethylammonium hydroxide peptizer on the synthesis of $\mathrm{Fe}_{3} \mathrm{O}_{4}$ $\mathrm{SiO}_{2}$ core/shell nanoparticles. Colloid Surface A. 2006;278:140-143.

22. Segal JB, Eng J, Tamariz LJ, Bass EB. Review of the evidence on diagnosis of deep venous thrombosis and pulmonary embolism. Ann Fam Med. 2007;5:63-73.

23. Løvlien M, Johansson I, Hole T, Schei B. Early warning signs of an acute myocardial infarction and their influence on symptoms during the acute phase with comparisons by gender. Gend Med. 2009;6:444-453.

24. Anderson HV, Willerson JT. Thrombolysis in acute myocardial infarction. New Engl J Med. 1993;329:703-709.

25. van der Worp HB, van Gijn J. Clinical practice: acute ischemic stroke. New Eng J Med. 2007;357:572-579.

26. Bennett W, Paoni N, Keyt B, et al. High resolution analysis of functional determination of human tissue-type plasminogen activator. J Biol Chem. 1991;266:5191-5520.

27. Berger H, Pizzo S. Preparation of polyethylene glycol-tissue plasminogen activator adducts that retain functional activity: characteristics and behavior in three animal species. Blood. 1988;71:1641-1647.

28. Stricker RB, Wong D, Shiu DT, Reyes PT, Shuman MA. Activation of plasminogen by tissue plasminogen activator on normal and thrombasthenic platelets: effects on surface proteins and platelet aggregation. Blood. 1986;68:275-280.

29. Xie Y, Kaminski MD, Torno MD, Finck MR, Liu X, Rosengart AJ. Physicochemical characteristics of magnetic microspheres containing tissue plasminogen activator. J Magn Magn Mater. 2007;311: 376-378.

30. Kaminski MD, Xie Y, Mertz CJ, Finck MR, Chen H, Rosengart AJ. Encapsulation and release of plasminogen activator from biodegradable magnetic microcarriers. Eur J Pharm Sci. 2008;35:96-103.

31. Ma YH, Wu SY, Wu T, Chang YJ, Hua MY, Chen JP. Magnetically targeted thrombolysis with recombinant tissue plasminogen activator bound to polyacrylic acid. Biomaterials. 2009;30:343-351.

32. Wu T, Hua MY, Chen JP, Wei KC, Jung SM, Chang YJ. Effects of external magnetic field on biodistribution of nanoparticles: a histological study. J Magn Magn Mater. 2007;311:372-375.

33. Janolino VJ, Swaisgood HE. A spectrophotometric assay for solid phase primary amino groups. Appl Biochem Biotechnol. 1992;36:81-85.

34. Liang JF, Song H, Li YT, Yang VC. A novel heparin/protamine-based pro-drug type delivery system for protease drugs. J Pharma Sci. 2000;89:664-673.

35. Berny MA, Patel IA, White-Adams TC, et al. Rational design of an ex vivo model of thrombosis. Cell Mol Bioeng. 2010;3:187-189.

36. Stöber W, Fink A, Bohn E. Controlled growth of monodisperse silica spheres in the micron size range. J Colloid Interf Sci. 1968;26:62-69.

37. Philipse AP, Van Bruggen MPB, Pathmamanoharan C. Magnetic silica dispersions: preparation and stability of surface-modified silica particles with a magnetic core. Langmuir. 1994;10:92-99.

38. Panella B, Vargas A, Ferri D, Baiker A. Chemical availability and reactivity of functional groups grafted to magnetic nanoparticles monitored in situ by ATR-IR spectroscopy. Chem Mater. 2009;21:4316-4322.
39. Hammond C. The Basics Of Crystallography and Diffraction. Oxford, UK: Oxford University Press; 1997.

40. Girgis E, Wahsh MMS, Othman AGM, Bandhu L, Rao KV. Synthesis, magnetic and optical properties of core/shell $\mathrm{Co}_{1-\mathrm{x}} \mathrm{Zn}_{\mathrm{x}} \mathrm{Fe}_{2} \mathrm{O}_{4} / \mathrm{SiO}_{2}$ nanoparticles. Nanoscale Res Lett. 2011;6:460.

41. Torno MD, Kaminski MD, Xie Y, et al. Improvement of in vitro thrombolysis employing magnetically-guided microspheres. Thrombosis Res. 2008;121:799-811.

42. Mahmoudi M, Sant S, Wang B, Laurent S, Sen T. Superparamagnetic iron oxide nanoparticles (SPIONs): development, surface modification and applications in chemotherapy. Adv Drug Deliv Rev. 2011;63:24-46.

43. Koneracka M, Kopcansky P, Antalik M, Timko M, Ramchand CN, Lobo D. Immobilization of proteins and enzymes to fine magnetic particles. J Magn Magn Mater. 1999;201:427-430.

44. Goissis G, Marcantonio E Jr, Marcantonio RAC, Lia RCC, Cancian DCJ, De Carvalho WM. Biocompatibility studies of anionic collagen membranes with different degree of glutaraldehyde cross-linking. Biomaterials. 1999;20:27-34.

45. Trowbridge EA, Crofts CE. The extension rate independence of the hysteresis in glutaraldehyde-fixed bovine pericardium. Biomaterials. 1987;8:201-206

46. Kempe H, Kempe M. The use of magnetite nanoparticles for implantassisted magnetic drug targeting in thrombolytic therapy. Biomaterials. 2010;31:9499-9510

47. Yoshioka S, Izutsu K, Aso Y, Takeda Y. Inactivation kinetics of enzyme pharmaceuticals in aqueous solution. Pharm Res. 1991;8:480-484.

48. Johnson PA, Park HJ, Driscoll AJ. Enzyme nanoparticle fabrication: magnetic nanoparticle synthesis and enzyme immobilization. Methods Mol Biol. 2011;679:183-191.

49. Hong J, Xu D, Gong P, Yu J, Ma H, Yao S. Covalent-bonded immobilization of enzyme on hydrophilic polymer covering magnetic nanogels. Microporous Mesoporous Mater. 2008;109:470-477.

50. Lee DG, Ponvel KM, Kim M, Hwang S, Ahn IS, Lee CH. Immobilization of lipase on hydrophobic nano-sized magnetite particles. J Mol Catal B Enzym. 2009;57:62-66.

51. Ganguly K, Krasik T, Medinilla S, et al. Blood clearance and activity of erythrocyte-coupled fibrinolytics. J Pharmacol Exp Ther. 2005;312: 1106-1113.

52. Loskutoff DJ, Sawdey M, Mimuro J. Type 1 plasminogen activator inhibitor. Prog Hemost Thromb. 1989;9:87-115.

53. Ganguly K, Murciano JC, Westrick R, Leferovich J, Cines DB, Muzykantov VR. The glycocalyx protects erythrocyte-bound tissuetype plasminogen activator from enzymatic inhibition. $J$ Pharmacol Exp Ther. 2007;321:158-164.

54. Madison EL, Goldsmith EJ, Gerard RD, Gething MJ, Sambrook JF, Bassel-Duby RS. Amino acid residues that affect interaction of tissuetype plasminogen activator with plasminogen activator inhibitor 1. Proc Natl Acad Sci U S A. 1990;87:3530-3533.

55. Diamond SL. Engineering design of optimal strategies for blood clot dissolution. Annu Rev Biomed Eng. 1999;1:427-462.

56. Diamond SL, Anand S. Inner clot diffusion and permeation during fibrinolysis. Biophys J. 1993;65:2622-2643.

57. Pleydell CP, David T, Smye SW, Berridge DC. A mathematical model of post-canalization thrombolysis. Phys Med Biol. 2002;47:209-224.

International Journal of Nanomedicine

\section{Publish your work in this journal}

The International Journal of Nanomedicine is an international, peerreviewed journal focusing on the application of nanotechnology in diagnostics, therapeutics, and drug delivery systems throughout the biomedical field. This journal is indexed on PubMed Central,

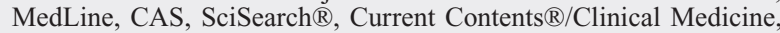

Journal Citation Reports/Science Edition, EMBase, Scopus and the Elsevier Bibliographic databases. The manuscript management system is completely online and includes a very quick and fair peer-review system, which is all easy to use. Visit http://www.dovepress.com/ testimonials.php to read real quotes from published authors. 